\title{
The Cause of Chinese Government Promoting College Students' Innovation and Entrepreneurship
}

\author{
Tuo Meimei \\ Shaanxi Fashion Engineering University, Xi'an, Shaanxi, China, 712046
}

Keywords: Chinese government; innovation and entrepreneurship; cause

\begin{abstract}
With the change of knowledge economy, the world economic pattern has changed from management to innovation. So, the project on innovation and entrepreneurship has become an important field of exploration in China. Encouraging innovation and entrepreneurship is an important way to promote China's economic transformation. In 2015, Chinese premier Li Keqiang pointed out that "mass entrepreneurship and innovation" has created a trend of innovation and entrepreneurship in China. At present, the Chinese government advocates innovative and entrepreneurial talents to jointly create an innovative society. For contemporary college students, it is the best time for innovation and entrepreneurship. Based on the background of China's current era, this paper studies the reasons why the Chinese government promotes the innovation and entrepreneurship of college students, and hopes that it can provide its own meager strength for the current entrepreneurial wave.
\end{abstract}

\section{Introduction}

Entrepreneurial innovation provides a strong reserve force for the country to implement innovation-driven strategy, and lays the foundation for China's economic transformation. Scientific and technological innovation has played a huge role in promoting China's development, and is the fundamental support of economic and social development. Innovation and entrepreneurship have stimulated the competition mechanism of the market and optimized the entrepreneurial environment with the help of the Chinese government. Which constantly stimulate the innovation vitality of the society. As the main force of the current state, the Chinese government has formulated a large number of preferential policies to help and support the innovation and entrepreneurship of college students. The innovation and entrepreneurship of college students has further promoted the informatization and industrialization of the Chinese market and stimulated the enterprise's ability to innovate.

\section{Promote the Necessity of College Students' Innovation and Entrepreneurship}

\subsection{Alleviate China's employment pressure.}

The process of self-employment will create new jobs and not only solve the employment pressure of graduates. At the same time, it has added jobs to other social workers, which can greatly alleviate the current employment pressure in Chinese society. Based on the above objectives, the Chinese government has formulated a number of preferential policies for helping and encouraging college students to innovate and start their own businesses. Meanwhile, new innovative projects can accelerate the transformation of Chinese society. With the development of Chinese society, the total number of college graduates has reached 7.95 million by 2017. The huge number of graduates will need to be adapted to jobs. With China's economy gradually saturated, the existing jobs cannot meet the employment of college students. So, self-employment has become an important way to alleviate college students' employment. For college students who accept education in the new era, they will be more suitable for entrepreneurship than other classes in their thinking and learning ability. So, in the current era most suitable for college students to start a business. College students should seize 
this opportunity to innovate in traditional industries and realize the transformation of China's economy.

\subsection{Broaden the employment channels for entrepreneurship.}

The Chinese government has issued preferential policies to promote the development of small and micro enterprises, "Internet $+"$ and innovative enterprises. We will broaden the channels for employment in Chinese society. At the same time, the Chinese government has promoted the return of college students to start their own businesses. College students' entrepreneurship promotes the upgrading and development of the surrounding area industry and improves the labor productivity of residents through their innovative thinking. The development of an industry will certainly lead to the common development of other industries. When formulating preferential policies, the Chinese government must consider the idea of diversified entrepreneurship among college students, and the preferential policies should be included in all walks of life. When setting up the preferential policies of entrepreneurship, different preferential policies should be formulated according to the advantages of different regions, so as to meet people's demand for products and promote the development of local economy.

\section{Promote Economic and Social development and Innovative Social Construction}

\subsection{Promote economic and social development.}

With the development of The Times, the trend of Chinese college students' entrepreneurship is increasing. As China's economic development strategy has been transformed from "traditional" to "innovation-oriented", the development mode integrates modern management, technology and operation, etc. We have provided a solid reserve for China to establish new economic forms through innovation in the system, theory and management. China attaches great importance to this economic form, while the United States, Japan and other economic powers also realize the rapid development of the national economy by changing the original economic model. China must follow the trend of the world, implement innovative strategies and accelerate the development of our economy. The United States was able to overtake the European powers in the twentieth century. It has a very big relationship with its continuing entrepreneurial innovation. Continuous innovation and entrepreneurship has great help in creating wealth and increasing labor productivity in the United States. The United States has maintained rapid economic development for nearly a hundred years because of the cultivation and protection of American innovation and entrepreneurship awareness. Under the development of innovation and entrepreneurship in the United States, the United States has produced a series of giant companies in various industries, such as Google, apple, etc.

Today, the entrepreneurial economy has played a decisive role in China's economic transformation. The innovation and entrepreneurship economy changed the production mode of traditional economy and abandoned the economic times of extensive production, high energy consumption and high pollution. The success of innovation and entrepreneurship has not only expanded one enterprise, but also strengthened one industry and even related industries. It has driven the industrial development of the whole economy. If the success of innovation and entrepreneurship is achieved through the perspective of industry development, the production pattern of the original industry will be changed and optimized. At the same time, it strengthens the importance of the whole society for innovation, and guarantees the enterprise's enterprising and innovative. In this respect, innovation and entrepreneurship is conducive to China's construction of innovative countries and to improve the speed and quality of economic development.

\subsection{Accelerate the construction of innovative society.}

Innovation is at the heart of the government's push, and companies maintain innovation to improve their core competitiveness, while the Chinese government advocates innovation to strengthen innovative social construction. Although China is now a major manufacturing country in the world, China has not yet completed the transformation of "made in China" to "create in China". 
So, in order to enhance the core competitiveness of the country in manufacturing industry and improve the country's long-term development and economic strength, China must promote innovation and entrepreneurship. The Chinese government has guided the country to an innovative country through innovation and entrepreneurship. In today's society, innovation is indispensable. Only by strengthening the cultivation of innovation consciousness can we succeed. Then through entrepreneurship to drive innovation, achievements. So, the cultivation of college students' innovation and entrepreneurial ability is the focus of current Chinese universities. This kind of innovation ability is crucial to China's innovative social construction. In the critical period of building a moderately prosperous society, the Chinese government must promote entrepreneurship through an innovative perspective. The Chinese government has completed the transformation of the Chinese economy and society and accelerated the construction of an innovative society. Innovation is the first driving force for the development of national science and technology. We must strengthen national innovation-driven development, achieve economic growth and speed up the construction of an innovative society.

\section{Conclusion}

The Chinese government is also actively creating conditions to encourage and support college graduates to start their own businesses and formulate policies and measures to support entrepreneurship. But we should also be aware that Chinese society is still in transition. Compared with the mature market environment in Europe and America, the load on the shoulders of Chinese college students is heavier. The various services needed for starting a business are not perfect, and the social supporting system of college students should be further established and improved. In the future, the government should further improve relevant policies to support entrepreneurship and innovation. We will improve the entrepreneurial service system, strengthen the support of emerging industry venture funds, and encourage support for college students' entrepreneurship through various channels of special funds. In addition, we can learn from the successful cases of education in the USA, and cover the entrepreneurial education in the students' learning and growth stage, so that the practice of education will be closer to the social market environment. In this way, the entrepreneurial motivation of college students can be stimulated and the success rate of college students' entrepreneurship can be improved.

\section{References}

[1] Jeffry A. Timmons: New denture Creation. Irwin McGraw Hill (1999) pp 212-215.

[2] Sang M. Lee \& Suzanne J. Peterson” entrepreneurial orientation, and global co-Mpetitiveness”. Journal of Worldiness (2000) pp 25-27

[3] Xavier S R, Kelley D, Kew Jetal 2013 GIobal Entrepreneur Monitor. Global Report. Global Entrepreneurship Monitor (2012) pp 35-37

[4] Amabile T M. Motivating Creativity in Organizations: On Doing What You Love and Loving What You Do. California Management Review (2014) pp 39 - 58

[5] Robinson, P. B. Sexton, E.A. The Effect of Education and Experience on Smalland Entrepreneurial Success. Journal of Business Verturing (2014) pp 141 - 156

[6] Potter J. Entrepreneurship and Higher Education: Future Policy Directions. Sourceoecd Education \& Skills volume (2013) pp 422 - 448

[7] Amabile T M. Motivating Creativity in Organizations: On Doing What You Love and Loving What You Do. California Management Review (2014) pp 39 - 58

[8] Robinson, P. B. Sexton, E.A. The Effect of Education and Experience on Smalland Entrepreneurial Success. Journal of Business Verturing (2014) pp 141 - 156 